\title{
Die bewerking van idiome in tweetalige woordeboeke*
}

\author{
Liezl Potgieter, Departement Afrikaans en Nederlands, Universiteit van \\ Stellenbosch, Stellenbosch, Republiek van Suid-Afrika \\ (liezlpotgieter@gmail.com)
}

Opsomming: Woordeboeke is belangrike en noodsaaklike hulpmiddels vir vertalers, maar tog het baie vertalers gemengde gevoelens oor veral tweetalige woordeboeke. Terwyl hulle aan die een kant nie werklik sonder hulle kan werk nie, bied tweetalige woordeboeke aan die ander kant dikwels vir die vertaler min of geen leiding. Dit blyk ook dat tweetalige woordeboeke nie voldoende hulpmiddels vir professionele vertalers is by die vertaling van idiome nie. Teorieë betreffende en benaderings tot vertaling word in die bespreking betrek. Die vertaling van idiome behels meer as net die vertaling van enkelwoorde. In hierdie artikel word aandag gegee aan die huidige bewerking van idiome in tweetalige woordeboeke sowel as die probleme waarmee vertalers gekonfronteer word by die vertaling van idiome.

Sleutelwoorde: IDIOOM, TWEETALIGE WOORDEBOEK, VERTAALEKWIVALWENT, ABSOLUTE EKWIVALENSIE, GEDEELTELIKE EKWIVALENSIE, DIVERGENSIE, ZERO-EKWIVALENSIE, SURROGAATEKWIVALENSIE, REGISTERVERSKILLE, ONVASTHEDE, TAALBOUSELS

Abstract: The Treatment of Idioms in Bilingual Dictionaries. Dictionaries are important and necessary aids for translators, but still many translators have mixed feelings especially regarding bilingual dictionaries. While on the one hand they cannot really work without them, on the other hand bilingual dictionaries often give the translator little or no guidance. It also appears that bilingual dictionaries are not sufficient aids for professional translators in the translation of idioms. Theories regarding and approaches to translation are broached in the discussion. The translation of idioms entails more than just the translation of single words. In this article, attention is given to the present treatment of idioms in bilingual dictionaries, as well as problems with which translators are confronted in the translation of idioms.

Keywords: IDIOM, BILINGUAL DICTIONARY, TRANSLATION EQUIVALENT, ABSOLUTE EQUIVALENCE, PARTIAL EQUIVALENCE, DIVERGENCE, ZERO EQUIVALENCE, SURROGATE EQUIVALENCE, DIFFERENCES IN REGISTER, VARIABLE UNITS, LANGUAGE UNITS

* Hierdie artikel is 'n uittreksel uit 'n ongepubliseerde M.A.-skripsie deur Liezl Gouws Die bewerking van idiome in tweetalige woordeboeke: 'n probleem vir vertalers? wat in April 2006 deur die Universiteit van Stellenbosch, Stellenbosch aanvaar is.

Lexikos 16 (AFRILEX-reeks/series 16: 2006): 180-192 


\section{Inleidend}

There is little doubt that dictionaries can be made to better serve their users, among whom translators constitute a very important group. (Roberts en Martin-Rutledge 1999)

Een van die groot tekortkominge in baie tweetalige woordeboeke is die bewerking van idiome. Die bewerkings wat gebruikers in woordeboeke aantref, is dikwels onvoldoende (Gouws 2005: 51) en veroorsaak meermale meer verwarring as duidelikheid. Ook wat betref Afrikaans-Engelse tweetalige woordeboeke, ervaar gebruikers dikwels probleme met idiome wat veroorsaak dat die vertaling van idiome meermale 'n moeilike en tydrowende proses is, bloot weens die gebrekkige bewerking van idiome in tweetalige woordeboeke. In hierdie artikel sal daar gekyk word na verskillende probleme waarmee vertalers en ander woordeboekgebruikers gekonfronteer word met betrekking tot die bewerking van idiome in tweetalige woordeboeke.

\section{Aanbieding}

Dictionaries are a valuable source of information about multiwords. Unfortunately, only few multiwords are explicitly marked as such in dictionaries: most of them are presented without being distinguished from free combinations of words. (Bentivogli en Pianta 2002)

Die aanbieding van meerwoordige items (insluitende idiome) in tweetalige woordeboeke is een van die redes waarom hierdie woordeboeke vertalers nie genoegsaam help tydens die vertaling van idiome nie. Die algemene tendens in Afrikaans-Engelse en ander tweetalige woordeboeke is dat idiome nie as onafhanklike leksikale items behandel word nie. Idiome word nie in Groot Woordeboek (voortaan GW) of in Pharos Afrikaans-Engels Woordeboek (voortaan PAEW) aangebied as deel van die makrostruktuur (met ander woorde as lemmas in die sentrale lys of in 'n aparte lys) nie, maar wel as deel van die mikrostruktuur (met ander woorde as deel van die bewerking van 'n betrokke lemma). (Sien ook Roberts en Martin-Rutledge 1999.) Lemmas kan as primêre bewerkingseenhede beskou word en die aanbieding van idiome sou baie meer geslaagd wees as dit nie net as deel van die mikrostruktuur van die artikel aangebied word nie, maar eerder as sekondêre bewerkingseenhede met minstens sublemmastatus. Deur die aanbieding van idiome in tweetalige woordeboeke sodanig te verbeter, sal die vertaler se soektog na 'n betrokke idioom baie vergemaklik word.

Sowel GW as PAEW gebruik 'n tradisionele leksikografiese prosedure wat behels dat idiome gewoonlik aangebied word as deel van die bewerking van een of meer van die woorde wat in die idioom voorkom (meestal by die naamwoorde of werkwoorde) (Gouws 2005: 51). Tog is hierdie tipe bewerking nie ideaal nie. Dit is belangrik om te onthou dat ' $n$ idioom ' $n$ uitdrukking is waar- 
van die betekenis nie uit die betekenisse van die dele daarvan afgelei kan word nie. Die feit dat 'n betrokke idioom nie lemmastatus verkry nie, maar in die bewerking van 'n lemma ingesluit word, impliseer dat daar 'n tipe semantiese verhouding tussen die lemma en die idioom bestaan (Gouws 1996: 69). Tog is dit nie altyd die geval nie. As voorbeeld kan gekyk word na die idioom "spill the beans" wat in sowel GW as PAEW as deel van die bewerking van "bean" aangetref word. Die vertaalekwivalente wat in die twee onderskeie woordeboeke vir "bean" verskaf word, is soos volg:

PAEW: boon(tjie); (i.d. mv.) bone, boontjies; (Am. infml.) kop.

GW: boontjie; ( $p l$.) boontjies; pitte (geld).

Alhoewel die idioom "spill the beans" onder die lemmateken "bean" bewerk word, toon die betekenis van die idioom, naamlik "om 'n geheim te verklap", geen ooreenkomste met enige van die betekenisonderskeidings van die leksikale item wat deur die lemmateken "bean" verteenwoordig word nie. Die Afrikaanse vertaalekwivalente wat vir die idioom verskaf word, naamlik "met die hele mandjie patats vorendag kom" (GW en PAEW) en "die aap uit die mou laat" (PAEW) toon ook geen semantiese verhouding met enige van die vertaalekwivalente van die lemma "bean" nie. Beide die brontaal- en die doeltaalvorme van die idioom se semantiese posisie binne die artikel van die lemma "bean" is dus onvanpas. Dit kan aan woordeboekgebruikers baie probleme verskaf in hul soektog na 'n vertaalekwivalent van 'n betrokke idioom omdat die gebruikers nie noodwendig sal weet waar in die woordeboek om na die idioom te gaan soek nie en omdat die idioom nie semanties pas by die lemma waaronder dit bewerk word nie.

'n Verdere probleem met die bewerking van idiome soos wat dit tans in GW en PAEW aangetref word, is dat die idiome as deel van die bewerking van die lemma aangebied word, tussen die ander voorbeeldsinne en kollokasies, maar sonder dat daar vir die woordeboekgebruiker aangedui word in watter gevalle hy/sy te make het met 'n koteksinskrywing en in watter van die gevalle daar sprake is van idiome. Dit is belangrik dat daar 'n onderskeid tussen idiome en voorbeeldmateriaal getref sal word en dat idiome nie as voorbeeldmateriaal aangebied en bewerk sal word nie, maar eerder lemma- of sublemmastatus sal kry. Indien idiome bloot as voorbeeldmateriaal bewerk word en daar nie aangedui word in watter gevalle die gebruiker te make het met ' $n$ idioom al dan nie, is daar geen manier om die idiome van ander letterlike voorbeeldsinne te onderskei nie en bemoeilik dit die vertaler se taak om eerstens die idioom in die betrokke artikel op te spoor, en tweedens om te weet in watter gevalle die voorbeeldsin 'n letterlike betekenis het en in watter gevalle die betekenis idiomaties is. Dit is daarom noodsaaklik dat die leksikograaf pertinent vir die gebruiker sal aandui in watter gevalle die woordkombinasies die letterlike gebruik van die lemma as koteksinskrywings demonstreer en in watter gevalle dit ' $n$ idiomatiese waarde het. 
'n Gebrek aan ruimte is dikwels een van die hoofredes waarom idiome as deel van die bewerking van 'n lemmateken behandel word, selfs al hou die betekenis van die idioom geensins verband met die betekenis van die leksikale item nie. Alhoewel die aanbieding van idiome as deel van die bewerking van 'n ander lemmateken (soos wat idiome tans in GW en PAEW behandel word) glad nie ideaal is vir woordeboekgebruikers nie, moet in ag geneem word dat die ruimte in 'n woordeboek beperk is en dat leksikograwe dikwels hierdie bewerking gebruik omdat daar soveel data in 'n relatief beperkte ruimte ingepas moet word. Juis daarom is die kanse skraal dat leksikograwe in die nabye toekoms van hierdie tipe bewerking van idiome sal wegbeweeg. Om dié rede is dit belangrik dat leksikograwe hierdie minder gewenste werkswyse so goed moontlik moet benut. Indien 'n leksikograaf geen ander uitweg het nie en besluit om ' $n$ idioom se aanbieding en bewerking te koppel aan die artikel van 'n lemma wat ooreenstem met 'n woord uit daardie idioom, is dit nodig dat die leksikograaf nie die idioom of idiome en die koteksinskrywings van die lemma bymekaar sal plaas sonder enige aanduiding van watter gevalle voorbeelde van watter tipe inskrywing is nie. Dit is daarom nodig dat idiome as sublemmas volwaardige bewerkingseenhede moet wees en dat die leksikograaf deur middel van nielemmatiese adressering (byvoorbeeld aanvullende inligting) of met behulp van ' $n$ verbeterde toegangstruktuur (deur die aanbring van byvoorbeeld 'n struktuurmerker) die idiome aan die gebruikers sal uitwys. Deur die aanwending van 'n struktuurmerker soos UITDR. (wat in die HAT gebruik word) of IDM. om die teksblok te merk waarin idiome aangebied word, maak die leksikograaf dit vir die woordeboekgebruikers moontlik om vinniger die idiome in die artikeltrajek raak te sien en 'n vertaalekwivalent op te spoor, omdat die idioom in 'n aparte soeksone val en dus nie tussen die voorbeeldsinne en kollokasies aangetref word nie.

\section{Vertaalekwivalente}

Die plek in die woordeboek waar idiome aangebied word, is nie die enigste probleem ten opsigte van die bewerking van idiome in tweetalige woordeboeke nie. Die vertaalekwivalente wat verskaf word en die bewerking daarvan is dikwels 'n nog groter probleem vir vertalers. In die meeste gevalle in GW en PAEW word daar by die bewerking van idiome aan die gebruiker 'n lys vertaalekwivalente verskaf met min of geen inligting rakende die doeltaalkonteks waarbinne die idiome gebruik behoort te word nie. In die volgende gedeelte sal gekyk word na verskeie probleme met betrekking tot die vertaalekwivalente wat vir idiome in tweetalige woordeboeke verskaf word.

\subsection{Ekwivalensie}

The main aim of the [bilingual] dictionary should not only be the establishment of semantic equivalence between source and target language. Instead a lexicographer has to endeavour to reach communicative equivalence. (Gouws 1996a: 16) 
Die tweetalige woordeboek as die vertaler se basiese hulpmiddel dien om intertalige oordrag moontlik te maak. Alhoewel die meeste Suid-Afrikaanse tweetalige woordeboeke daarin slaag om die gebruiker te help om semantiese ekwivalensie te bereik (waar daar een of meer vertaalekwivalente vir 'n betrokke woord verskaf word), is daar min Suid-Afrikaanse tweetalige woordeboeke wat gebruikers voldoende help om ook kommunikatiewe ekwivalensie te bereik.

Wanneer 'n tweetalige woordeboek geraadpleeg word, is dit meestal om 'n vertaalekwivalent te vind om 'n spesifieke woord, uitdrukking of idioom in die brontaal mee te vervang in die doeltaal. In teenstelling met wat dikwels gedink word, kan 'n spesifieke vertaalekwivalent in 'n tweetalige woordeboek nie sommer arbitrêr as die betekenis van die leksikale item beskou word nie. 'n Vertaalekwivalent is 'n doeltaalitem wat gebruik kan word om die brontaalitem binne 'n spesifieke situasie te vervang, afhangende van spesifieke kontekstuele en kotekstuele beperkings (Gouws 2002). In gevalle waar die woordeboek egter nie aan die gebruiker enige konteks- of koteksleiding verskaf nie, is dit vir die gebruiker dikwels baie moeilik om binne die doelteks kommunikatiewe ekwivalensie te bereik.

Volgens Gouws (1996a: 16) bestaan daar wel 'n verhouding van ekwivalensie tussen die lemma (of in hierdie geval die idioom) en die onderskeie vertaalekwivalente wat in die betrokke woordeboekartikel aangebied word (die vertaalekwivalentparadigma). Hy noem verder dat leksikograwe moet probeer om vertaalekwivalensie te bereik, wat impliseer dat daar 'n semantiese koördinasie tussen die lemma en sy vertaalekwivalentparadigma moet bestaan. Dit is volgens Gouws (1996a: 17) ook belangrik dat vertaalekwivalente aangevul behoort te word met bykomende inligting en voorbeeldmateriaal wat die tipiese gebruikskonteks illustreer. Die probleem is dat sommige leksikograwe hulle pogings om vertaalekwivalensie te bereik, tot slegs die lys van 'n aantal doeltaalitems beperk. Alhoewel hierdie items wel die semantiese waarde van die lemma verteenwoordig en semantiese ekwivalensie skep, word daar aan die gebruiker geen hulp gebied om die korrekte ekwivalent vir die spesifieke konteks te kies nie. Soos Martin (1962: 156) met reg sê:

Sometimes the uncritical heaping up of near-synonyms is simply an evasion of responsibility on the part of the dictionary-maker: unable (or too little informed) to make up his own mind, he shifts the burden of choice to the user of the dictionary.

Net soos in gevalle waar vertalers tweetalige woordeboeke vir die soek van 'n vertaalekwivalent vir 'n enkelwoord gebruik, is die bereiking van kommunikatiewe ekwivalensie hul hoofdoel wanneer hulle na 'n vertaalekwivalent vir 'n betrokke idioom soek. Dit is daarom noodsaaklik dat leksikograwe ook in die geval van idiome aan die vertaalekwivalentparadigma aandag sal gee en dat vertaalekwivalente van idiome met voorbeeldmateriaal en addisionele inligting aangevul word om die gebruiker te help om vinnig en maklik die korrekte 
vertaalekwivalent op te spoor. Deur aanvullende inligting soos konteks- en koteksleiding te gebruik, kan daar verseker word dat die lemma (of in hierdie geval die idioom) en die vertaalekwivalent in 'n verhouding van kommunikatiewe ekwivalensie tot mekaar staan. Semantiese en kommunikatiewe ekwivalensie in woordeboeke lei in die praktyk dikwels ook tot dit waarna Newmark (1982: 39) verwys as "semantiese vertalings" en "kommunikatiewe vertalings". Hy beskryf hierdie twee tipes vertalings soos volg:

Communicative translation attempts to produce on its readers an effect as close as possible to that obtained on the readers of the original. Semantic translation attempts to render, as closely as the semantic and syntactic structures of the second language allow, the exact contextual meaning of the original.

Dit is wenslik dat vertalers eerder kommunikatiewe vertalings as semantiese vertalings sal gebruik, veral ten opsigte van die vertaling van idiome. Juis daarom is dit belangrik dat leksikograwe die lemma en die onderskeie vertaalekwivalente in 'n verhouding van kommunikatiewe ekwivalensie met mekaar sal laat staan, om vertalers te help om 'n kommunikatiewe vertaling as eindproduk te kry.

Daar bestaan verskillende tipes ekwivalensie binne die leksikografie. Daarom moet leksikograwe nie alle vertaalekwivalente eenders bewerk nie, maar die woordeboekgebruikers attent maak op die verskillende tipes ekwivalensie en ook aan hulle uitwys watter tipe ekwivalentverhouding in watter gevalle geld. Sodoende kan leksikograwe die woordeboekgebruikers help om die korrekte vertaalekwivalent vir ' $n$ betrokke idioom binne 'n spesifieke teks en konteks te vind.

Die belangrikste tipes ekwivalensie wat onder vertaalekwivalente aangetref word, is absolute ekwivalensie, gedeeltelike ekwivalensie (wat divergensie insluit) en zero-ekwivalensie (wat surrogaatekwivalensie insluit). Vervolgens sal elk van hierdie tipes ekwivalensie ten opsigte van die vertaling van idiome bespreek word.

\subsubsection{Absolute ekwivalensie}

Absolute ekwivalensie kom voor wanneer die vertaalekwivalent(e) wat verskaf word in die doeltaal die woord of frase in die brontaal binne alle kontekste en omstandighede kan vervang. Idiome en hul vertaalekwivalente word dikwels in tweetalige woordeboeke as absolute ekwivalente aangegee. In gevalle waar die brontaalidioom en die doeltaalidioom absolute ekwivalente is en dus kongruent aan mekaar is, is daar 'n een-tot-een-verhouding tussen die bron- en die doeltaal. Daar bestaan dus sowel semantiese as kommunikatiewe ekwivalensie tussen die bron- en die doeltaal. In gevalle waar daar absolute ekwivalensie tussen die brontaalidioom en die doeltaalidioom is, bestaan daar ook dikwels 'n verhouding van ekwivalente idiomatisiteit tussen die twee idiome. Sodanige idiome kan dus gewoonlik maklik en probleemloos vertaal word. 
Tog gebeur dit ook dikwels dat 'n vertaalekwivalent as 'n absolute ekwivalent vir ' $n$ idioom aangegee word, alhoewel dit nie die geval is dat die doeltaalidioom absoluut ekwivalent aan die brontaalidioom is nie. In sodanige gevalle is dit nodig dat die leksikograaf die gebruiker attent sal maak op die feit dat die twee idiome nie absoluut ekwivalent is nie. Dit is daarom nodig dat die vertaalekwivalent as 'n gedeeltelike ekwivalent bewerk sal word en nie as 'n absolute ekwivalent nie.

\subsubsection{Gedeeltelike ekwivalensie en divergensie}

Idiome het dikwels meer as een vertaalekwivalent, maar daar word selde aan woordeboekgebruikers enige leiding verskaf ten opsigte van watter ekwivalent om binne 'n bepaalde konteks te kies. Dikwels word die onderskeie ekwivalente as absolute ekwivalente aangedui en alhoewel gevalle wel voorkom waar een of meer vertaalekwivalente absoluut kan wees, gebeur dit meer dikwels dat die vertaalekwivalente slegs gedeeltelik ekwivalent is of dat daar 'n verhouding van divergensie tussen die lemma (of idioom) en die vertaalekwivalente bestaan.

Een van die belangrike aspekte van die bewerking van idiome in tweetalige woordeboeke waaraan leksikograwe aandag moet gee, is die hantering van divergensie. Divergensie kom in artikels voor waar daar 'n een-tot-meer-aseen-verhouding tussen die bron- en die doeltaal is, en waar die leksikograaf spesiale aandag aan die hantering van die vertaalekwivalentparadigma moet gee. In artikels waar daar 'n verhouding van divergensie voorkom, is dit eerstens belangrik dat die leksikograaf tussen leksikale en semantiese divergensie sal onderskei. Volgens Gouws (2002) geld leksikale divergensie in gevalle waar 'n lemma meer as een vertaalekwivalent het, maar waar die vertaalekwivalente in die doeltaal absolute sinonieme of gedeeltelike sinonieme is.

In die geval van leksikale divergensie word die onderskeie vertaalekwivalente in hierdie woordeboeke met behulp van kommas (,) van mekaar geskei. Dit is egter noodsaaklik dat die leksikograaf sal aandui indien die vertaalekwivalente slegs gedeeltelik sinoniem is. In gevalle van absolute sinonimie kan die vertaler die vertaalekwivalent op dieselfde manier hanteer as wat met die behandeling van kongruensie in die woordeboek plaasvind. Indien daar vir die gebruiker geen konteks- of koteksleiding gegee word nie, kan hy/sy van die veronderstelling uitgaan dat die onderskeie vertaalekwivalente almal dieselfde semantiese waarde het. In gevalle van gedeeltelike sinonimie is dit belangrik dat die leksikograaf die gebruiker daarop attent sal maak dat die gedeeltelike sinonieme as vertalings van die brontaalvorm dien, maar dat hulle mekaar nie binne alle kontekste in die doeltaal kan vervang nie. Dit is daarom noodsaaklik dat die leksikograaf konteks- of koteksleiding by die onderskeie vertaalekwivalente sal voeg, sodat die gebruiker sal weet wat die tipiese konteks is waarbinne watter vertaalekwivalent normaalweg voorkom en waar die algemene semantiese waarde van die vertaalekwivalent geaktiveer word (Gouws 2002). 
Semantiese divergensie kom voor wanneer 'n lemma meer as een vertaalekwivalent het omdat die betrokke brontaalvorm polisemies is. In gevalle van semantiese divergensie word die verskillende polisemiese waardes in GW en PAEW met behulp van kommapunte (;) geskei. Volgens Gouws (1989: 168) is polisemiese lemmas (en dus ook idiome) vanuit 'n semantiese oogpunt een van die vertalende leksikograaf se grootste probleme. Die bewerking van die idioom "keep an eye (up)on" in GW is 'n voorbeeld van 'n artikel waarin daar semantiese divergensie voorkom. Terwyl die eerste vertaalekwivalent "dophou" volgens die HAT soos volg gedefinieer word: "in die oog hou; let op dikwels met onvriendelike bybedoeling", word die tweede vertaalekwivalent wat verskaf word (" 'n oog hou oor") in Prinsloo (2004: 252) so omskryf: "bewaak, sorg vir".

Die probleem is dat daar nie aan die gebruiker gesê word wat die semantiese verskille tussen die verskillende vertaalekwivalente is nie en dat daar ook nie onderskei word watter van die vertaalekwivalente idiome is en watter nie. Indien 'n vertaler nie bewus is van die semantiese verskille tussen die onderskeie vertaalekwivalente nie, kan dit maklik gebeur dat hy/sy die verkeerde ekwivalent binne die betrokke doelteks en -konteks kies. In gevalle soos hierdie is dit belangrik dat die leksikograaf die gebruiker sal help om die regte vertaalekwivalent vir die regte konteks te kies. Die beste manier waarop die leksikograaf kommunikatiewe ekwivalensie kan waarborg, is deur addisionele inskrywings in te voeg om die gebruiker te help sodat hy/sy sal kan aflei watter vertaalekwivalent die korrekte een is om te gebruik.

Dit gebeur ook dikwels dat daar binne een artikel beide leksikale en semantiese divergensie voorkom. In sodanige gevalle van polidivergensie is dit weereens noodsaaklik dat die leksikograaf genoeg konteks- en koteksleiding sal verskaf en duidelik sal onderskei tussen die sinonieme, gedeeltelike sinonieme en poliseme sodat dit steeds vir die gebruiker duidelik sal wees watter vertaalekwivalent binne watter konteks gebruik moet word om sodoende kommunikatiewe ekwivalensie te kan bewerkstellig.

By die voorkoms van vertaalekwivalente waar daar 'n verhouding van divergensie (hetsy leksikale divergensie, semantiese divergensie of polidivergensie) bestaan, is dit dus nodig dat leksikograwe van aanvullende notas en glosse gebruik sal maak om aan die gebruiker die nodige konteksleiding te verskaf. Veral vertalers werk dikwels onder groot tyddruk en aanvullende notas en glosse sal hulle help om makliker en vinniger die gepaste ekwivalent op te spoor deur die soektog te vereenvoudig en te verkort.

\subsubsection{Zero-ekwivalensie en surrogaatekwivalensie}

Dit gebeur ook dat daar idiome in die brontaal bestaan waarvoor daar nie vertaalekwivalente in die doeltaal is nie. Sodanige gevalle is voorbeelde van wat as "zero-ekwivalensie" bekend staan. By gevalle van zero-ekwivalensie is dit belangrik dat die idiome nie net uit die woordeboek weggelaat sal word nie, maar dat hulle inderdaad ook bewerk sal word. Alhoewel dit nie vir die verta- 
ler moontlik sal wees om in 'n geval van zero-ekwivalensie die idioom in die brontaal met ' $n$ idioom in die doeltaal te vertaal nie, is dit noodsaaklik dat die vertaler steeds die idioom, tesame met die nodige bewerking daarvan, in die tweetalige woordeboek sal kan vind. Dit is belangrik dat die leksikograaf dit nie aan die vertaler se intuïsie sal oorlaat om af te lei dat, aangesien die brontaalidioom nie 'n geskikte doeltaalidioom het nie, die idioom daarom nie in die woordeboek opgeneem is nie. Dit is gewoonlik juis die idiome waarvoor daar nie 'n doeltaalvorm bestaan nie wat vir vertalers die moeilikste is om suksesvol weer te gee (of op 'n ander manier te bewerk). Dit is dus noodsaaklik dat die leksikograaf die vertaler daarop sal attent maak dat daar nie 'n geskikte doeltaalvorm vir die idioom bestaan nie en voorts ook die alternatiewe maniere waarop die idioom in die doeltaal oorgedra kan word, aan die vertaler sal uitwys.

Die beste en maklikste manier om sodanige idiome te bewerk is deur van surrogaatekwivalensie gebruik te maak. Surrogaatekwivalensie behels dat daar vir die brontaaltaalitem (in hierdie geval 'n idioom) 'n surrogaatvertaalekwivalent verskaf word. Aangesien die surrogaatekwivalent juis benodig word vanweë die afwesigheid van 'n beter vertaalekwivalent, is 'n surrogaatekwivalent dikwels 'n omskrywing van die betrokke woord of idioom. Dit is daarom belangrik dat daar vir die gebruiker aangedui word wanneer die vertaalekwivalent in die doeltaal ' $n$ idioom is en wanneer nie, deur dit byvoorbeeld met ' $n$ asterisk te merk om hom/haar van die nie-idiomatisiteit bewus te maak. Dit gebeur ook dikwels dat, alhoewel daar nie 'n ekwivalente idioom in die doeltaal bestaan nie, daar wel 'n enkelwoord in die doeltaal is om die idioom mee te vervang. Ook in sodanige gevalle is dit noodsaaklik dat die gebruiker daarop attent gemaak sal word dat die vertaalekwivalent nie 'n enkelwoordidioom is nie, maar slegs 'n enkelwoord.

\subsection{Register- en ander verskille}

In die meeste Suid-Afrikaanse tweetalige woordeboeke word idiome relatief selde van etikette, glosse of konteks- en koteksleiding voorsien. Die woordeboekgebruiker sal meestal slegs ' $n$ idioom en 'n lys vertaalekwivalente aantref. Tog, net soos sommige enkelwoorde, word sekere idiome ook net binne sekere kontekste en sekere registers gebruik. Dit is belangrik dat die leksikograaf die woordeboekgebruiker ook in die bereiking van kommunikatiewe ekwivalensie sal help deur genoegsame leiding te verskaf ten opsigte van wat 'n betrokke idioom se register is en binne watter tipe teks en konteks dit gebruik behoort te word. Die aanwending van etikette, glosse en konteks- en koteksleiding maak ekwivalentonderskeiding makliker vir die woordeboekgebruiker en help hom/ haar om te besluit watter doeltaalitem om te kies vir 'n betrokke situasie.

Alhoewel daar registeretikette in beide PAEW en GW aangetref word, is dit meestal net die brontaalitem se register wat aangedui word. Die doeltaalitem word meestal ongeëtiketteer gelaat. Tog is dit belangrik dat leksikograwe in 'n poging om woordeboekgebruikers te help om kommunikatiewe ekwiva- 
lensie te bereik, ook aan registerekwivalensie aandag sal gee. Dit beteken dat die leksikograaf daarop moet let om vertaalekwivalente van dieselfde register te verskaf, of om, indien die register van die brontaalitem en die doeltaalitem verskil, etikette te gebruik om dit pertinent onder die woordeboekgebruiker se aandag te bring. Dit is ook noodsaaklik dat die leksikograaf beide die brontaalen die doeltaalitems sal bewerk om die gebruiker in te lig rakende register en nie net die brontaalitems te bewerk en te aanvaar dat die woordeboekgebruiker self sal weet wat die register van die doeltaalitems is nie. Sodoende kan leksikograwe vertalers help om te besluit watter vertaalekwivalent om binne watter styl en register te gebruik.

\section{Onvasthede by idiome}

Alhoewel daar talle idiome is wat heeltemal vas en verstar is en waarby daar niks weggeneem, gewysig of bygevoeg kan word nie, is die oorgrote meerderheid idiome op sekere wyses veranderbaar, smeebaar en onvas (Combrink 1989: 57). In die volgende gedeelte sal gekyk word na bepaalde wyses waarop idiome onvas kan wees, sowel as die huidige hantering daarvan in GW en PAEW.

\subsection{Opsionele bykomstige taalbousels}

Volgens Combrink (1989: 57) is party idiome onvas in dié opsig dat ekstra taalbousels in die idioom ingelas kan word, maar nie noodwendig ingelas hoef te word nie. Moontlike inlasstukke sluit in: opsionele bykomstige woordgroepe, woorde en woorddele.

'n Tweetalige woordeboek behoort, volgens Combrink (1989: 58), die algemeen gangbare, opsionele bykomstige woorde in idiome aan te gee, maar moet hulle konsekwent merk as opsioneel bykomstig. Die algemeenste manier om opsionele bykomstige woordgroepe, woorde of woorddele te merk, is deur hulle tussen hakies te plaas.

Die probleem wat dikwels in tweetalige woordeboeke aangetref word wat betref die aanbieding van idiome met opsionele bykomstige taalbousels, is dat hulle dikwels óf weggelaat word óf verkeerdelik aangedui word asof hulle 'n wesenlike deel van die betrokke idioom is. By die bewerking van die idioom "spill the beans" word die Afrikaanse vertaalekwivalent "met die (hele) mandjie patats vorendag kom" aangetref. In PAEW word die woord "hele" tussen hakies aangedui as 'n opsionele taalbousel, alhoewel dit nie so aangetoon word in GW nie. 'n Vertaler wat van GW gebruik maak om die betrokke idioom te vertaal, sal dus nie weet dat die woord "hele" nie 'n wesenlike deel van die idioom is nie, maar 'n opsionele taalbousel wat wel weggelaat kan word. Vir die vertaler om die idioom korrek te kan vertaal, is dit noodsaaklik dat opsionele bykomstige taalbousels pertinent aangedui sal word. Dit is nodig dat leksikograwe sal let op die bewerking van taalbousels en sal probeer om hulle op 'n konsekwente en verbruikersvriendelike wyse aan te bied. 


\subsection{Opsionele bykomstige negatiewe woorde}

Combrink (1989: 59) noem dat negatiewe woorde 'n addisionele tipe is waaraan die leksikograaf spesiale aandag behoort te skenk by die aangawe van idiome in tweetalige woordeboeke. Daar bestaan idiome soos byvoorbeeld "nothing to write home about" wat oorspronklik slegs in die negatief voorgekom het (alhoewel dit deesdae al hoe meer ook in die positief gebruik word), maar daar is ook verskeie idiome wat in sowel die positief as die negatief gebruik kan word en wat met behulp van woorde soos geen, g'n, nie, niemand, niks en nooit negatief gemaak kan word.

As ' $n$ bepaalde idioom in die positief én die negatief voorkom (met ander woorde as ' $n$ bepaalde idioom opsioneel bykomstig die inlas van ' $n$ negativeerder toelaat), kan dit volgens Combrink (1989: 60) verwarrend wees as slegs die negatief aangedui word en dit dan nie as opsioneel bykomstig gemerk word nie. Die beste leiding wat ' $n$ tweetalige woordeboek in verband met idiome aan sy gebruikers kan gee, is deur die basiese idioomvorm as sodanig saam met die opsionele bykomstige elemente aan te dui. Die rede waarom dit belangrik is dat die idioom in sy basiese vorm in woordeboeke aangegee sal word, is dat, as die idioom slegs in die negatief aangegee word, gebruikers verkeerdelik die gevolgtrekking kan maak dat die idioom slégs in die negatief gebruik mag word. 'n Leksikograaf kan egter nie by al die idiome wat in die woordeboek voorkom, sowel die positief as die negatief aandui nie omdat dit te veel plek sal opneem. Daarom noem Combrink (1989: 60) dat die negatiewe variant (naas die basiese positiewe) slegs aangegee hoef te word as die negatief een of meer vertalings het wat nie uit die positiewe aangawe afgelei kan word nie. Dit is noodsaaklik dat inligting oor wanneer ' $n$ idioom in sowel die positief as die negatief gebruik kan word en wanneer ' $n$ idioom slegs in die negatief aangewend kan word, pertinent aan gebruikers uitgewys sal word. Juis om hierdie rede ag Combrink (1989: 60) dit so belangrik dat die idioom altyd in die basiese idioomvorm vermeld sal word.

\subsection{Alternatiewe bykomstige taalbousels}

Volgens Combrink (1989: 62) is daar by idiome ook onvasthede wat hy "alternatiewe woorde en woordgroepe" noem. Hierdie alternatiewe bousels is nóg opsioneel nóg bykomstig. Anders as by opsionele bykomstige taalbousels, gaan dit nie in hierdie geval oor die vraag of die gebruiker die bousel wil gebruik al dan nie, maar oor 'n keuse deur die gebruiker tussen twee of meer verpligte bousels.

In PAEW word alternatiewe bykomstige taalbousels sowel in die brontaal as in die doeltaal aangedui met behulp van óf hakies en die woorde "or" of "of" óf 'n skuinsstreep (/) om die alternatiewe aan die gebruiker uit te wys en hulle terselfdertyd te onderskei van die opsionele bykomstige taalbousels wat ook tussen hakies aangedui word. Hierdie verskillende aanbiedings van die alter- 
natiewe bousels kan gebruikers maklik verwar omdat hulle nie noodwendig sal besef dat daar in beide gevalle sulke bousels gegee word nie. Hierdie inkonsekwente aanbieding is selfs nog meer verwarrend as beide vorme van aanbieding in een artikel voorkom, veral wanneer daar boonop nie net alternatiewe bousels in die artikel aangetref word nie, maar ook 'n verskeidenheid opsionele bousels. Dit is belangrik dat die leksikograaf die data op so 'n wyse sal aanbied dat die gebruiker (of vertaler) maklik sal kan aflei wat dit presies is wat die leksikograaf probeer weergee en hoe hy/sy die inligting wat in die betrokke artikel aangebied word, in sy/haar teks kan of moet gebruik.

Die aanbieding van alternatiewe taalbousels in GW is ook nie juis geslaagd nie, omdat sowel opsionele as alternatiewe taalbousels op presies dieselfde manier behandel word en die gebruiker op geen manier kan weet wanneer dit ' $n$ opsionele taalbousel en wanneer dit ' $n$ alternatiewe taalbousel is nie.

Nog 'n probleem wat ontstaan by die aanbieding van alternatiewe taalbousels is wanneer die woordeboek nie al die verskillende alternatiewe in die artikel aanbied nie, maar slegs een van die alternatiewe, en dit dan boonop laat lyk asof die alternatief nie slegs ' $n$ alternatief is nie, maar ' $n$ wesenlike deel van die betrokke idioom.

'n Voorbeeld van so 'n geval waar die alternatiewe taalbousels nie pertinent aangedui word nie, is die idioom "to see something in a certain light". In hierdie idioom kan die woord "certain" vervang word met een van 'n verskeidenheid byvoeglike naamwoorde, byvoorbeeld "to see something in a good light", "to see something in a bad light" of "to see something in a different light". Tog bly die basiese idioom in die doeltaal deurgaans dieselfde, naamlik "om iets in 'n goeie/slegte/ander lig te beskou". In GW word hierdie idioom nêrens gelys nie en in PAEW word slegs die opsie "to see something in a different light" verskaf.

Dié wyse van aangawe soos dit in PAEW aangetref word, laat dit ten onregte lyk asof "different" 'n wesenlike deel van die betrokke idioom is, terwyl dit juis nie die geval is nie. 'n Vertaler wat byvoorbeeld die idioom "to see something in a bad light" moet vertaal en PAEW raadpleeg, sal nie noodwendig weet dat hierdie idioom op dieselfde wyse vertaal kan word as die idioom "to see something in a different light" wat in PAEW vermeld word nie. Juis daarom is dit belangrik dat ten minste al die algemeenste alternatiewe vir die gebruiker uitgewys sal word en dat die alternatiewe bousels slegs as alternatiewe aangedui sal word en nie as wesenlike dele van die idioom nie.

\section{Ten slotte}

Dit is duidelik dat daar baie ruimte vir verbetering is ten opsigte van die bewerking van idiome in tweetalige woordeboeke. Dit is daarom noodsaaklik dat daar aandag gegee sal word aan die behandeling van idiome in tweetalige woordeboeke om dit sodanig te verbeter dat dit gebruikersvriendeliker en 'n groter hulp vir vertalers sal wees. 


\section{Bronnelys}

\section{Woordeboeke}

Eksteen, L.C. 199714. Groot Woordeboek Afrikaans-Engels/Engels-Afrikaans / Major Dictionary Afrikaans-English/English-Afrikaans. Kaapstad: Pharos.

Odendal, F.F. en R.H. Gouws. 20004. Verklarende Handwoordeboek van die Afrikaanse Taal. Midrand: Perskor.

Du Plessis, M. (Hoofred.). 2005. Pharos 1, Afrikaans-Engels/English-Afrikaans Woordeboek/Dictionary. 2005. Kaapstad: Pharos Woordeboeke.

\section{Ander bronne}

Bentivogli, L. en E. Pianta. 2002. Detecting Hidden Multiwords in Bilingual Dictionaries. Braasch, A. en C. Povlsen (Reds.). 2002. Proceedings of the Tenth EURALEX International Congress, EURALEX 2002, II: 785-793. Kopenhagen: Center for Sprogteknologi. Intyds beskikbaar by: <http://tcc.itc.it/people/pianta/publications/euralex-collocations02.pdf> [24 Februarie 2005].

Combrink, J.G.H. 1989. Wesenlike elemente, ekstras en vulsels in die aangawe van idiome in tweetalige woordeboeke. Botha, T.J.R. (Red.). Leksikografie en leksikologie: 55-77. Menlopark: Serva Uitgewers.

Gouws, R.H. 1989. Leksikografie. Kaapstad: Academica.

Gouws, R.H. 1996. Idioms and Collocations in Bilingual Dictionaries and their Afrikaans Translation Equivalents. Lexicographica 12: 54-88.

Gouws, R.H. 1996a Bilingual Dictionaries and Communicative Equivalence for a Multilingual Society. Lexikos 6: 14-31.

Gouws, R.H. 2002. Leksikografie: Ekwivalentverhoudinge in vertalende woordeboeke. Ongepubliseerde Klasnotas Afrikaans 348.

Gouws, R.H. 2005. Issues Regarding the Comment on Semantics in Bilingual Dictionaries Dealing with Closely Related Languages. Igla, B., P. Petkov en H.E. Wiegand (Reds.). 2005. Kontrastive Lexikologie und zweisprachige Lexikographie. Germanistische Linguistik 179: 39-56. Hildesheim: Georg Olms Verlag.

Martin, S.E. 1962. Selection and Presentation of Ready Equivalents in a Translation Dictionary. Householder, F.W. en S. Saporta (Reds.). Problems in Lexicography: 153-159. Bloomington: Indiana University Press.

Newmark, P. 1982. Approaches to Translation. Oxford: Pergamon Press.

Prinsloo, A.F. 2004. Spreekwoorde en waar hulle vandaan kom. Kaapstad: Pharos.

Roberts, R. en V. Martin-Rutledge. 1999. Dictionary Use Strategies for Translators. Awaiss, H. en J. Hardane (Reds.). 1999. Traduction: Approches et Théories: 345-364. Beiroet: Skool van Vertalers en Tolke van Beiroet, Sint Josef Universiteit. Intyds beskikbaar by: <http://www.dico. uottawa.ca/articles-en.htm> [30 Mei 2005]. 